\title{
Chemical and isotopic features of Li-rich brines from the Salar de Olaroz, Central Andes of NW Argentina
}

\author{
M. Gabriela Franco ${ }^{\text {a,b, }}$, Yesica J. Peralta Arnold ${ }^{\text {b }}$, Carla D. Santamans ${ }^{\mathrm{b}}$, \\ Romina L. López Steinmetz ${ }^{\mathrm{b}}$, Franco Tassi ${ }^{\mathrm{c}, \mathrm{d}}$, Stefania Venturi ${ }^{\mathrm{c}, \mathrm{d}}$, Cynthia B. Jofré ${ }^{\mathrm{b}}$, \\ Pablo J. Caffe ${ }^{\mathrm{b}}$, Francisco E. Córdoba ${ }^{\mathrm{b}}$ \\ ${ }^{a}$ Instituto de Geología y Minería, Universidad Nacional de Jujuy, Av. Bolivia 1661, S.S. de Jujuy, 4600, Argentina \\ ${ }^{\mathrm{b}}$ Instituto de Ecorregiones Andinas (INECOA), Universidad Nacional de Jujuy - CONICET, S.S. de Jujuy, 4600, Argentina \\ ${ }^{\mathrm{c}}$ Department of Earth Sciences, University of Florence, Via La Pira 4, 50121, Firenze, Italy \\ ${ }^{\mathrm{d}}$ CNR-IGG Institute of Geosciences and Earth Resources, Via La Pira 4, 50121, Firenze, Italy
}

\section{A R T I C L E I N F O}

\section{Keywords:}

Andean plateau

Northern puna

Salar de Olaroz

Hydrogeochemistry

Lithium-rich brine

\begin{abstract}
A B S T R A T
The lithium-rich brines of the Salar de Olaroz in the Central Andes of NW Argentina are considered to be of great economic and strategic interest. This study focused on the fluid source(s) and geochemical processes governing the chemical and isotopic characteristics of the surficial waters of Olaroz (residual brines, ephemeral lakes, rivers and tributary streams), aiming to define the mechanisms leading to such a huge Li reservoir. The chemistry of the Rosario River, which is one of the main sources of recharge of the Salar de Olaroz, is mostly controlled by fluid inputs from hydrothermal systems located north of the salar (in the volcanic areas of Rosario de Coyaguayma, Pairique, and Cono Panizo). The hydrothermal fluids are characterized by relatively high Li concentrations, as they interact with Li-rich rocks pertaining to Miocene - Pliocene volcanic formations, Ordovician sedimentary deposits, and, possibly, pre-Ordovician crystalline basement. In the salar, the hyperarid climate regulates the relative proportion between supplied waters and evaporation, inducing deposition/dissolution of salts, which controls the concentrations of main ions in brines and ephemeral lakes. Hence, the peculiar combination of a Lirich primary source, the hydrothermal scavenging by geothermal fluids that feed the Rosario River, and secondary concentration processes affecting the surficial water within the salar leads to the formation of the huge $\mathrm{Li}$ reservoir characterizing this area.
\end{abstract}

\section{Introduction}

The Altiplano-Puna Plateau (APP) in the Central Andes is the world's second highest plateau (mean altitude $\sim 4000 \mathrm{~m}$ a.s.l.) after the Tibetan plateau. Endorheic basins in the APP host saline lakes, playa-lakes and salt pans that are known as salars (Risacher et al., 2003; Risacher and Fritz, 2009). The arid regional climate is characterized by a strong precipitation deficit (Garreaud et al., 2009; Morales et al., 2015), intense solar radiation, large daily temperature fluctuations, strong winds and frequent frosts (even during the Austral summer). Climate controls the hydrology of these basins that are characterized by an extremely negative water balance. In this South American region, informally known as the Lithium Triangle, up to $80 \%$ of the world's brine lithium resources occur (Warren, 2010; Kesler et al., 2012; Munk et al., 2016; Flexer et al., 2018). Due to their economic and strategic interest, Li-rich continental brines of the Bolivian and northern Chile portions of the Andean Plateau have been largely investigated (Moraga et al., 1974; Rettig et al., 1980; Risacher et al., 1999, 2003; Risacher and Fritz, 1991, 2000, 2009; Munk et al., 2018; Moran et al., 2019). Specific attention was given to the chemistry of brines in Andean salars, providing conceptual geochemical models for circulating fluids (Warren, 2010; Houston et al., 2011; Munk et al., 2018). Hydrothermal fluids, whose chemistry reflects the interaction between meteoric waters and Andean crustal rocks (Perkins et al., 2016; Peralta Arnold et al., 2017; Chiodi et al., 2019; Tapia et al., 2019), were considered to be one of the main sources for the Andean Li-rich brines (Lowenstein and Risacher, 2009; Houston et al., 2011; Munk et al., 2011; Godfrey et al., 2013; López Steinmetz et al., 2018; Garcia et al., 2020). Brines concentrate as evaporation (i.e., water loss) induces salt precipitation (Eugster, 1980; Munk et al., 2018). Geochemical data of brine-type deposits from the southeastern sector of the plateau

\footnotetext{
* Corresponding author. Instituto de Geología y Minería, Universidad Nacional de Jujuy, Av. Bolivia 1661, S.S. de Jujuy, 4600, Argentina.

E-mail address: mgfranco@unju.edu.ar (M.G. Franco).
} 
(Argentine Puna Altiplano), e.g. Hombre Muerto and Olaroz salars, were recently reported (Orberger et al., 2015; López Steinmetz, 2017; López Steinmetz et al., 2018; Orocobre, 2019; Garcia et al., 2020), remarking the importance of these areas for exploitation purposes. Specifically, Salar de Olaroz (Fig. 1) is of great economic interest, being ranked as one of the richest in the world, with resources estimated at 1.50 million tonnes (Kesler et al., 2012), characterized by extremely high Li, B and K concentrations and optimal Li/Mg ratios (López Steinmetz et al., 2018).
As part of a multidisciplinary approach carried out to investigate the formation of Li-rich deposits in the northern Puna, the present study focuses on investigating the fluid source(s) and geochemical processes governing the chemical and isotopic features of surficial waters (residual brines, ephemeral lakes, rivers and tributary streams).
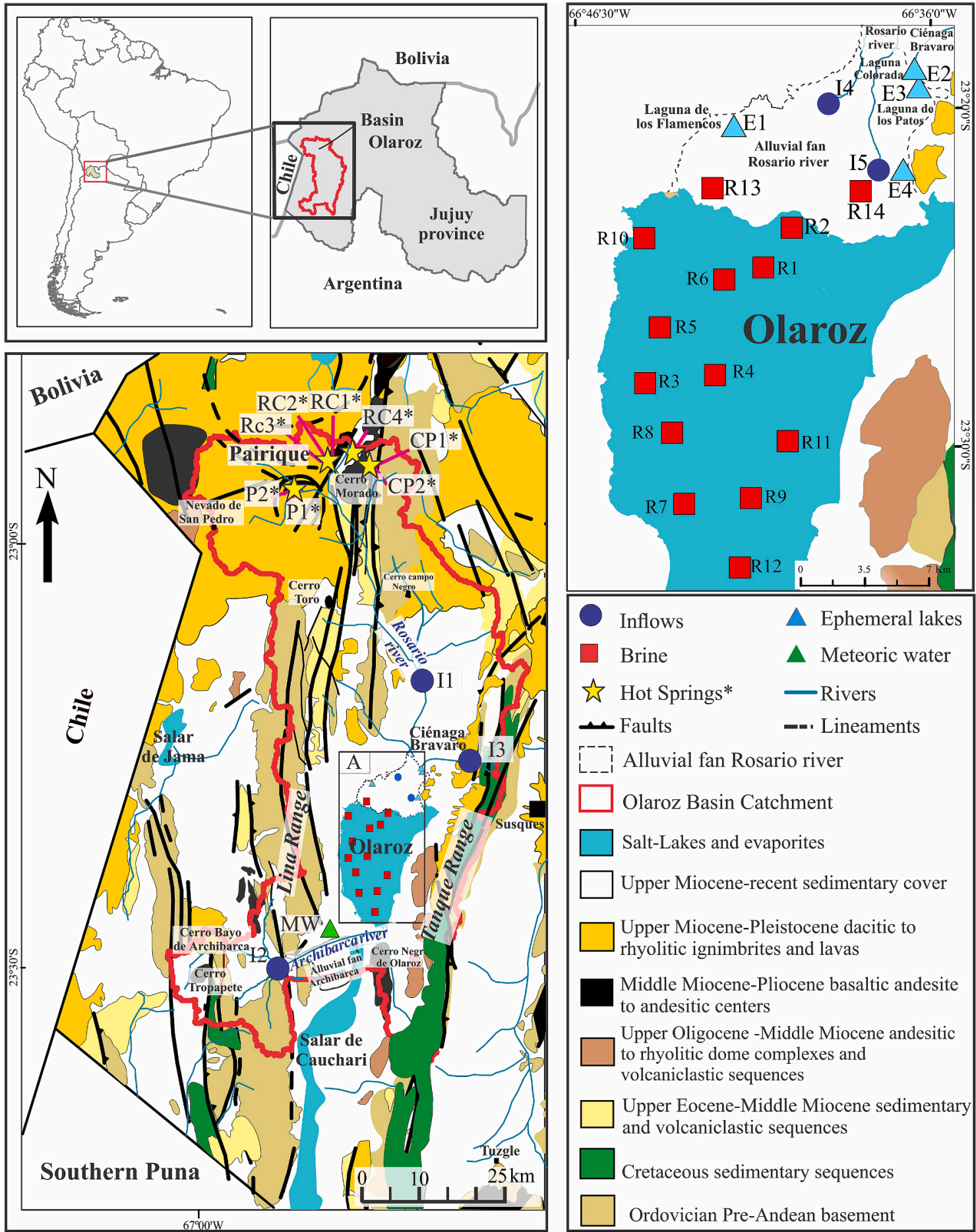

Fig. 1. Geological map of the Olaroz basin, northern Puna (Argentina) (modified from Caffe et al., 2002), with the location of the sampling sites within the salar and alluvial fan of the Rosario River. Blue circle: inflow water; light blue triangle: ephemeral lake; red square: brine. (For interpretation of the references to color in this figure legend, the reader is referred to the Web version of this article.) 


\section{Study area}

\subsection{Morphological and hydrological features}

Salar de Olaroz is part of the Olaroz-Cauchari endorheic basin, and is located in the northern part of the Argentine plateau $\left(24^{\circ} 05^{\prime} \mathrm{S}\right.$ and $66^{\circ} 40^{\prime} \mathrm{W}, 3950 \mathrm{~m}$ a.s.1.; Fig. 1). The salar has an area of $3567 \mathrm{~km}^{2}$, being bordered to the south by the alluvial fan of the Archibarca River, whereas the Tanque and Lina north-south trending ranges delimit the salar to the east and west, respectively. To the north, the salt pan extends up to the latitude $23^{\circ} 22^{\prime} 37.73^{\prime \prime}$, where it transitions to an alluvial plain.

The Salar de Olaroz is linked with an extensive endorheic basin hosting permanent rivers and many ephemeral streams. Waters flowing to the salar include (i) precipitation (during the Austral summer) and (ii) surface-subsurface drainage and groundwater (Orocobre, 2019). The Rosario and Archibarca rivers are perennial, although before reaching the salar their waters disappear from the surface as they infiltrate into the permeable alluvial fan deposits (Fig. 1). With a mean annual base flow of $\sim 8.5 \times 10^{6} \mathrm{~m}^{3}$, the Rosario River is the most important source of superficial recharge to the salar (Orocobre, 2019). When surface water enters the salar, the river generates an extensive alluvial fan where cold and hot springs emerge (Fig. 1). The Rosario headwaters include several hydrothermal springs in different parts of the catchment areas (Peralta Arnold et al., 2017, Fig. 1). The Archibarca River is the second most important feeding system to the Salar de Olaroz and its outlet consist of a huge $\left(\sim 35 \mathrm{~km}^{2}\right)$ distributive fluvial system (or megafan; Weissmann et al., 2015) that separates Olaroz from the Salar de Cauchari. Although the megafan of Archibarca imposes a surface drainage divide, the hydraulic connection between Olaroz and Cauchari cannot be ruled out (Orocobre, 2019). Eventually, ephemeral streams located along the eastern and western salar margins, which are active only during the rainy season, act as minor tributaries.

The Salar de Olaroz morphology consists of distal distributive fluvial systems surrounding the flat central area hosting the typical halitedominated salt pan and its associated typical depositional subenvironment (Hardie et al., 1978; Smoot and Lowenstein, 1991; Warren, 2010), such as polygonal salt crusts (subaerial halite nucleus) and a marginal dry mudflats and desiccated saline mudflats (Franco et al., 2018). Each depositional sub-environment of the salar has its own suite of minerals, sediments and sedimentary structures, and their distribution is controlled by climate, hydrology and position in the drainage basin (Franco et al., 2016, 2018).

Previous information about the chemistry of the Olaroz brines, including Li contents (up to $1213 \mathrm{mg} / \mathrm{L}$ ), was reported in technical reports by mining companies (Orocobre, 2019) and scientific papers (López Steinmetz et al., 2018; Garcia et al., 2020).

\subsection{Geological setting}

The Salar de Olaroz is surrounded by ranges that expose the basement (Fig. 1), which consists of early Ordovician metasedimentary rocks (Acoite Formation, Floian - Darriwillian; Turner, 1964; Bahlburg et al., 1990; Albanesi and Ortega, 2016). The Ordovician sequences are covered by sedimentary deposits of the Salta Group (Cretaceous-Paleocene; Turner, 1959; Marquillas et al., 2005). Paleogene to Lower Miocene reddish fluvial conglomerates, as well as calcareous sandstones of the Log Log, Vizcachera and Peña Colorada Formations (Oligocene to Lower Miocene; Coira et al., 2004: Seggiaro et al., 2015), uncomformably cover the Salta Group rocks. These formations are followed by Middle Miocene to Pleistocene volcanic units (Coira et al., 1993; Seggiaro, 1994; Soler et al., 2007; Seggiaro et al., 2015; Maro and Caffe, 2017), interbedded with fluvial and lacustrine deposits including evaporites of the Loma Blanca and Sijes Formations (Alonso, 1986) and fluvial-alluvial deposits of the Pastos Chicos-Trinchera Formations (Schwab, 1973). The stratigraphic record culminates with Quaternary deposits consisting of alluvial fans (Fig. 1), playa lake and salars (Franco et al., 2018).

\subsection{Climate}

The climate in the northern Puna region is characterized by intense solar radiation and extreme daily temperature fluctuations (Buitrago and Larran, 2000), persistent winds, and a strong hydrological deficit (Morales et al., 2015). Aridity is caused by the local atmospheric circulation patterns combined with orographic effects (Garreaud et al., 2003, 2009; Vuille and Keimig, 2004). The Atlantic Ocean is the main source of moisture, leading to a rainy period during the Austral summer. The marked precipitation seasonality is controlled by the South American Monsoon System (SAMS) that is strongly influenced by the dynamics of the Bolivian High (Garreaud et al., 2003, 2009; Vuille and Keimig, 2004; Vuille et al., 2012). The northern Westerlies circulation regulates the moisture input from the north-northeast by reducing the precipitation rates from north to south and from east to west across the APP (Garreaud et al., 2003). Likewise, inter-annual precipitation varies due to the climatic impact of El Niño-Southern Oscillation (ENSO). High rainfall in the Altiplano-Puna region is usually associated with La Niña (Vuille, 1999; Garreaud et al., 2003, 2009). Annual rainfalls in Salar de Olaroz averages $170 \mathrm{~mm}$, mostly occurring from December to March. Consequently, a strong water deficit characterizes the rest of the year, producing a negative hydrological balance which favors evaporation and the formation of salars (Hardie and Eugster, 1970; Eugster and Hardie, 1978; Warren, 2010).

\section{Materials and methods}

Three major groups of waters were collected from Salar de Olaroz and its surroundings, as follows (Table 1): (1) inflow waters, (2) ephemeral lakes and (3) brines. Inflow waters (blue circles, Fig. 1) include (i) rivers (Rosario, I1; Archibarca, I2; Ciénaga Bravaro, I3) and (ii) creeks (I4 and I5), located at the middle part of the Rosario alluvial fan (Fig. 1). Ephemeral lakes (light blue triangles; Fig. 1) are located in the Rosario River alluvial fan (Fig. 1) comprising Laguna de los Flamencos (E1), Laguna Colorada (E2), Laguna de Los Patos (E3), and Laguna Rosario (E4). The latter was completely dried out during our surveys, thus the water sampling was carried out at a depth of $0.56 \mathrm{~m}$. Brines (red squares) were collected at $5-150 \mathrm{~cm}$ depths from dug pits, and include samples collected from (i) the saline nucleus (R1, R3 to R9 and R11), (ii) peripheral areas (R2, R10, and R12), and (iii) one shallow (0.69 m depth) well and one spring (R13 and R14, respectively) located in the Rosario alluvial fan (Fig. 1). The water samples were collected during four field campaigns carried out in February 2015, September 2015, April 2016 and October 2016.

Two aliquots of waters were filtered in situ using $0.45 \mu \mathrm{m}$ filters, one of them was acidified with ultrapure $\mathrm{HNO}_{3}$. Temperature, $\mathrm{pH}$, and electrical conductivity were measured using a portable multi-parameter (Hanna $\mathrm{HI}$ 98195). Alkalinity $\left(\mathrm{HCO}_{3}^{-}+\mathrm{CO}_{3}^{2-}\right.$ ) was analyzed by acidimetric titration (AT) using a digital titrator Hach model 16900 with $0.01 \mathrm{M} \mathrm{HCl}$ as titrant. Main anions $\left(\mathrm{F}^{-}, \mathrm{Cl}^{-}, \mathrm{SO}_{4}^{2-}\right.$, and $\left.\mathrm{F}^{-}\right)$and cations $\left(\mathrm{Ca}^{2+}, \mathrm{Mg}^{2+}, \mathrm{Na}^{+}, \mathrm{K}^{+}\right.$, and $\left.\mathrm{Li}^{+}\right)$were analyzed at the Laboratory of Fluid Geochemistry of the Department of Earth Sciences of Florence (Italy) by ion-chromatography (IC), using Metrohm 761 and Metrohm 861 chromatographs, respectively. The analytical error for AT and IC analyses was $\leq 5 \%$.

The $\mathrm{Cl}^{-}$, and $\mathrm{SO}_{4}^{2-}$ analysis of samples from the ephemeral lakes were carried out at the geochemistry laboratory of the CICTERRA-UNC by IC (Thermo Scientific), whereas their cations were analyzed at the INQUIMAE-UBA using Inductively Coupled Plasma Atomic Emission Spectroscopy (ICP-AES, SPECTRO Modula Flame). The analytical error for ICP-AES analysis was $\leq 5 \%$. Temperatures, $\mathrm{pH}$, Total Dissolved Solids (TDS, in $\mathrm{mg} / \mathrm{L}$ ), and concentrations (in $\mathrm{mg} / \mathrm{L}$ ) are listed in Table 1.

The ${ }^{18} \mathrm{O} /{ }^{16} \mathrm{O}$ and ${ }^{2} \mathrm{H} /{ }^{1} \mathrm{H}$ ratios of water (expressed as $\delta^{18} \mathrm{O}-\mathrm{H}_{2} \mathrm{O}$ and 


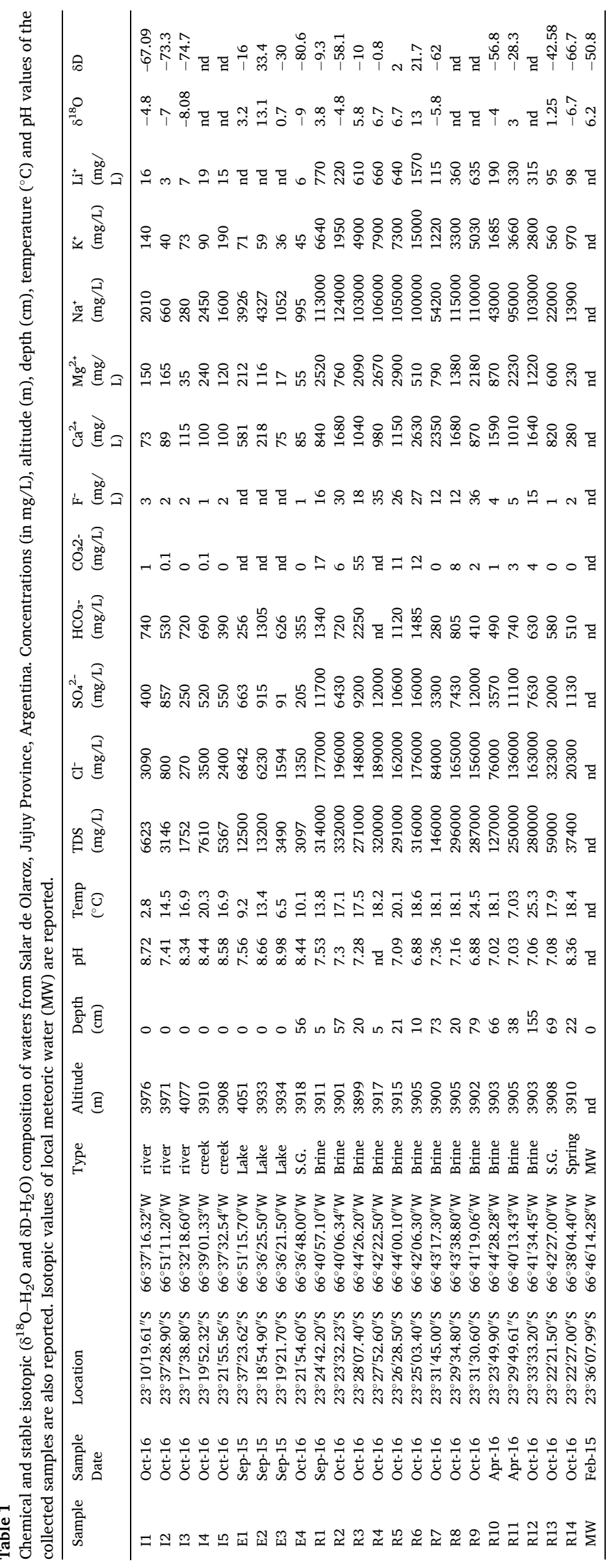


$\delta \mathrm{D}-\mathrm{H}_{2} \mathrm{O} \%$ vs. V-SMOW, respectively) were determined by wavelength scanned cavity ring-down spectrometry (Picarro L-2120-i CRDS) at the Laboratory GEA-IMASL of the National University of San Luis, Argentina. The analytical errors for CRDS analysis were $<0.1 \%$ and $<0.5 \%$, respectively.

Saturation indexes (SI) of gypsum, dolomite, aragonite, calcite, anhydrite, glauberite, halite mirabilite, sylvite and thenardite were computed using the computer code PHREEQC 3.4.0 with Pitzer database. The SI calculations based on measured geochemical parameters, i. e. temperature, $\mathrm{pH}$, and $\mathrm{Cl}^{-}, \mathrm{SO}_{4}^{2-}, \mathrm{HCO}_{3}^{-}, \mathrm{CO}_{3}^{2-}, \mathrm{Ca}^{2+}, \mathrm{Mg}^{2+}, \mathrm{Na}^{+}, \mathrm{K}^{+}$, and $\mathrm{Li}^{+}$concentrations (Table 1 ). Precipitation is supposed to occur for those minerals showing positive SI values (over-saturation conditions).

\section{Results}

\subsection{Chemical compositions}

Inflow waters have temperature from 2.80 to $20.30{ }^{\circ} \mathrm{C}, \mathrm{pH}$ from 7.34 to 8.72 , and TDS values from 1752 to $6623 \mathrm{mg} / \mathrm{L}$. They are of the $\mathrm{Na}^{+} /$ $\mathrm{Cl}^{-}$type, except for samples I2 and I3 that show $\mathrm{Na}^{+}-\mathrm{SO}_{4}^{2-}\left(\mathrm{Cl}^{-}\right)$and $\mathrm{Na}^{+}-$ $\mathrm{HCO}_{3}^{-}\left(\mathrm{Cl}^{-}\right)$compositions, respectively (Fig. 2a and b). All these waters have moderate concentrations of $\mathrm{Li}+$ (up to $19 \mathrm{mg} / \mathrm{L}$ ).

Ephemeral lakes are characterized by temperatures from 6.50 to $13.40{ }^{\circ} \mathrm{C}, \mathrm{pH}$ values ranging between 7.56 and 8.98, TDS from 3097 to $13,200 \mathrm{mg} / \mathrm{L}$, and they show a $\mathrm{Na}^{+}-\mathrm{Cl}^{-}$composition (Fig. 2a and b). Garcia et al. (2020) reported $\mathrm{Li}^{+}$concentrations for these ephemeral lakes (not available for samples E1-E3) ranging from 38 to $167 \mathrm{mg} / \mathrm{L}$.

Brines have $\mathrm{pH}$ values ranging from 6.88 to 8.36 , temperature spanning $7.03-25.3^{\circ} \mathrm{C}$, and TDS values from 37,400 to $332,000 \mathrm{mg} / \mathrm{L}$. These waters are of the $\mathrm{Na}^{+}-\mathrm{Cl}^{-}$type (Fig. $2 \mathrm{a}$ and b) and show the highest concentrations of $\mathrm{Li}^{+}$(up to $1500 \mathrm{mg} / \mathrm{L}$ ).

\subsection{Isotopic $\left(\delta^{18} \mathrm{O}-\mathrm{H}_{2} \mathrm{O}\right.$ and $\left.\delta \mathrm{D}-\mathrm{H}_{2} \mathrm{O}\right)$ values}

The $\delta^{18} \mathrm{O}-\mathrm{H}_{2} \mathrm{O}$ and $\delta \mathrm{D}-\mathrm{H}_{2} \mathrm{O}$ values of meteoric water (MW) are $-6.2 \%$ and -50.8 vs. VSMOW, respectively (Table 1 ). The $\delta^{18} \mathrm{O}-\mathrm{H}_{2} \mathrm{O}$ and $\delta \mathrm{D}-\mathrm{H}_{2} \mathrm{O}$ values of inflow waters range from $-8.08 \%$ to $-4.8 \%$ and from $-74.7 \%$ to $-67.09 \%$ vs. VSMOW, respectively. Ephemeral lakes have $\delta^{18} \mathrm{O}-\mathrm{H}_{2} \mathrm{O}$ values ranging from $-9 \%$ to $13.1 \%$ vs. VSMOW and $\delta \mathrm{D}-$ $\mathrm{H}_{2} \mathrm{O}$ values from $-80.6 \%$ to $33.4 \%$ vs. VSMOW. Brines have $\delta^{18} \mathrm{O}-\mathrm{H}_{2} \mathrm{O}$ values from $-6.7 \%$ to $13 \%$ vs. VSMOW and $\delta \mathrm{D}-\mathrm{H}_{2} \mathrm{O}$ values from $-66.7 \%$ to $21.7 \%$ vs. VSMOW. As shown in Fig. 3, all samples have marked ${ }^{18} \mathrm{O}$ - and $\delta \mathrm{D}$-positive shifts with respect to the Local Meteoric Water Line (LMWL) $\left(\delta \mathrm{D}=8.3 \times \delta^{18} \mathrm{O}+11.67\right.$; Peralta Arnold et al., 2017) and fit $\left(\mathrm{r}^{2}=0.97\right)$ on the following evaporation line: $\delta \mathrm{D}=4.86 \times$ $\delta 180-35.5$.

\subsection{Saturation index}

Most inflow waters were over-saturated with respect to calcite, dolomite and aragonite (except sample I2 that approaches saturation only respect to aragonite, Table 2). Samples collected from the ephemeral lakes are undersaturated with respect to all the salts (except sample E4 which is over-saturated with respect to aragonite, calcite, and dolomite). Most brine samples are over-saturated in aragonite, calcite, dolomite, anhydrite (except samples R7, R10, R13, and R14), gypsum (except samples R7, R10, R13, and R14), glauberite, and halite (except samples R7, R10, R11, R13, and R14).

\section{Discussion}

\subsection{Chemical-physical processes controlling water chemistry}

Based on the $\delta^{18} \mathrm{O}-\mathrm{H}_{2} \mathrm{O}$ and $\delta \mathrm{D}-\mathrm{H}_{2} \mathrm{O}$ values (Table 1 ) and considering the $\delta^{18} \mathrm{O}-\mathrm{H}_{2} \mathrm{O}$ fractionation factor due to the altitude $(-2.62$ units per $1000 \mathrm{~m}$; Peralta Arnold et al., 2017), the recharge area can be recognized at the intercept between the LMWL and the evaporation line fitting the investigated waters, corresponding to an altitude ranging from 5000 to $5500 \mathrm{~m}$ a.s.l. This recharge altitude, significantly higher than that suggested by the values of the local rain water (MW; Fig. 3), is consistent with the hypothesis that the northern sector of the basin, with altitudes up to 5800 m a.s.l. (e.g. Nevado de San Pedro; Fig. 1), feeds the Rosario River. Some of these hydrothermal springs significantly supply the Rosario River, and are related to the same hydrological system involving volcanic rocks, tuffs, fluvio-lacustrine sediments and evaporitic deposits, as supported by the relatively high TDS of the $\mathrm{Na}^{+}-\mathrm{Cl}^{-}$-type I1 sample (Table 1 and Fig. 1).

Partially mature waters showing a $\mathrm{Na}^{+}-\mathrm{Cl}^{-}$compositions were recognized in the Pairique area. Peralta Arnold et al. (2017) proposed the occurrence of a deep hydrothermal reservoir hosted within the Paleozoic crystalline basement (not outcropping in the area). According to the $\delta^{18} \mathrm{O}-\mathrm{H}_{2} \mathrm{O}$ and $\delta \mathrm{D}-\mathrm{H}_{2} \mathrm{O}$ values, these authors suggested that the hydrothermal reservoir is mainly recharged by meteoric water, although some contribution of andesitic water were not completely ruled out.
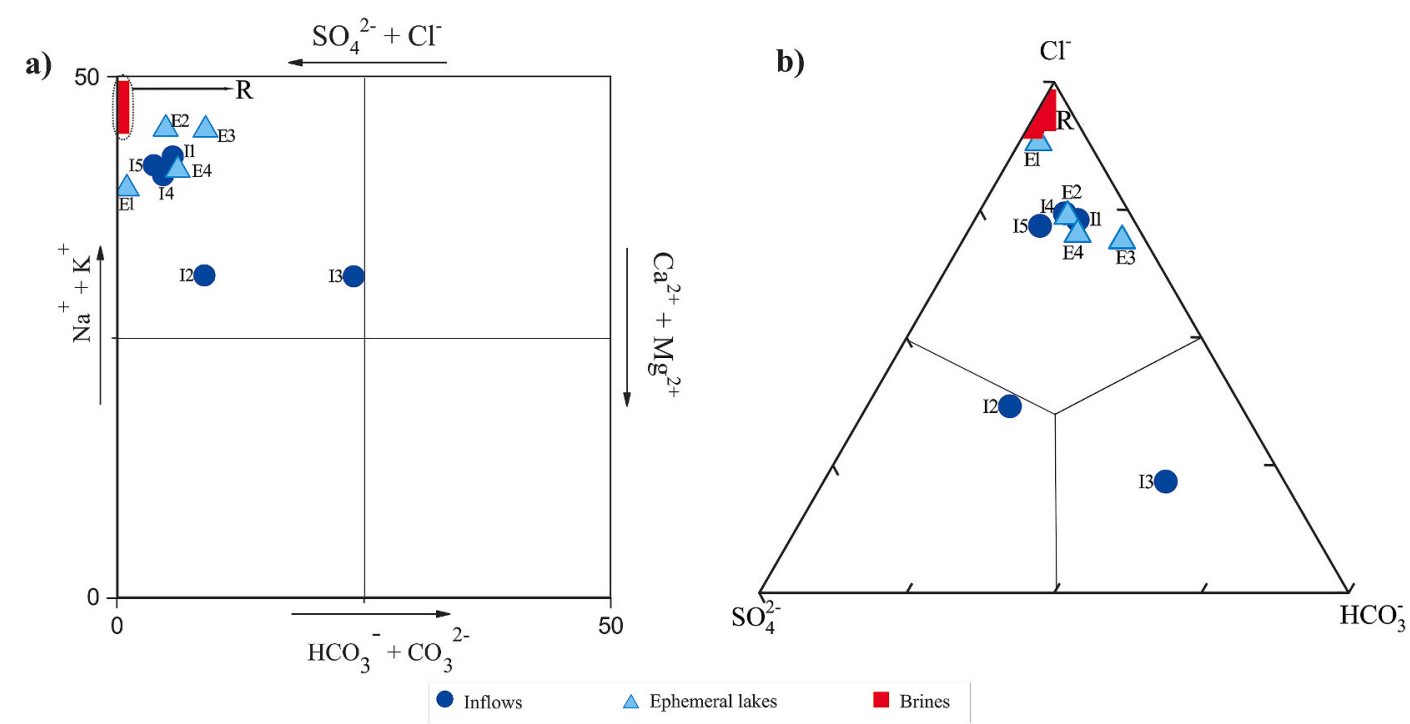

Fig. 2. (a) Langelier-Ludwig diagram (Langelier and Ludwig, 1942), and (b) $\mathrm{SO}_{4}^{2-}-\mathrm{Cl}^{-}-\mathrm{HCO}_{3}^{-}$ternary diagram for water samples from the Salar de Olaroz. $\mathrm{R}$ : brine group. 


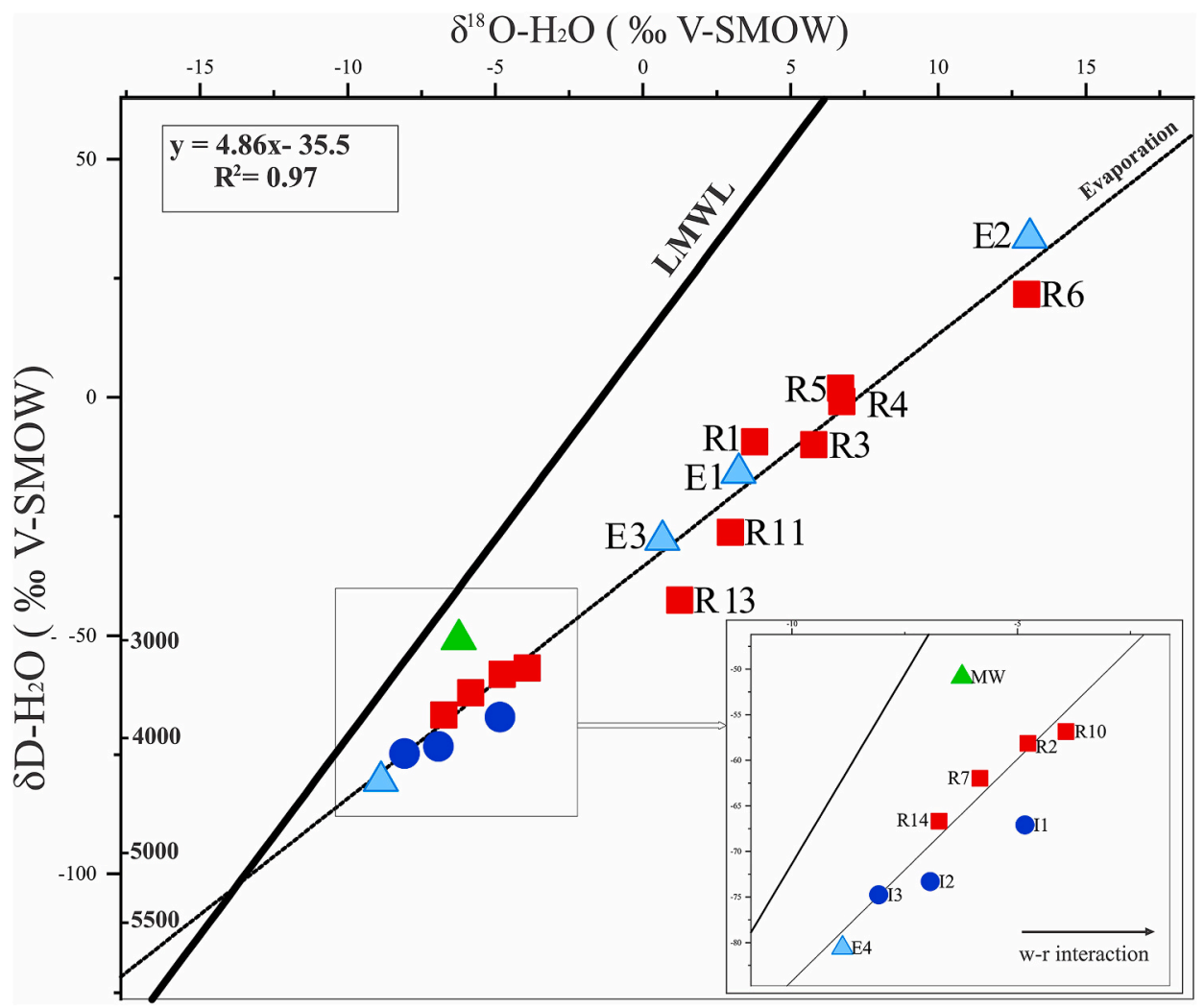

Fig. 3. $\delta \mathrm{D}-\mathrm{H}_{2} \mathrm{O}$ vs. $\delta^{18} \mathrm{O}-\mathrm{H}_{2} \mathrm{O}$ binary diagram for waters from the Salar de Olaroz. The Local Meteoric Water Line (LMWL) (Peralta Arnold et al., 2017) and the isotopic values of meteoric water (MW; green triangle) are reported. The altitude of the recharging area is shown on the vertical axis. Symbols of Olaroz waters as in Fig. 1. (For interpretation of the references to color in this figure legend, the reader is referred to the Web version of this article.)

Table 2

Saturation indices for waters from Salar de Olaroz. S.G.: shallow groundwater.

\begin{tabular}{|c|c|c|c|c|c|c|c|c|c|c|}
\hline Sample & Anhydrite & Aragonite & Calcite & Dolomite & Glauberite & Gypsum & Halite & Mirabilite & Sylvite & Thenardite \\
\hline I1 & -2.17 & 1.0 & 1.26 & 3.02 & -6.18 & -1.53 & -3.85 & -2.91 & -4.35 & -5.08 \\
\hline $\mathrm{I} 2$ & -1.49 & -0.01 & 0.22 & 0.99 & -6.09 & -1.00 & -4.92 & -4.04 & -5.61 & -5.51 \\
\hline I3 & -1.66 & 1.33 & 1.57 & 2.88 & -7.40 & -1.21 & -5.72 & -5.27 & -5.81 & -6.62 \\
\hline I4 & -1.80 & 1.15 & 1.41 & 3.48 & -5.73 & -1.40 & -3.79 & -3.62 & -4.74 & -4.78 \\
\hline I5 & -1.70 & 1.05 & 1.29 & 2.94 & -5.85 & -1.25 & -4.10 & -3.69 & -4.74 & -5.03 \\
\hline E1 & -1.23 & nd & nd & nd & -4.72 & -0.68 & -3.29 & -2.71 & -4.44 & -7.84 \\
\hline E2 & -1.43 & nd & nd & nd & -4.68 & -0.94 & -3.30 & -2.66 & -4.62 & -4.17 \\
\hline E3 & -2.49 & nd & nd & nd & -7.53 & -1.90 & -4.38 & -4.12 & -5.22 & -6.06 \\
\hline E4 & -2.08 & 0.5 & 0.71 & 1.47 & -6.87 & -1.54 & -4.50 & -4.50 & -5.25 & -5.76 \\
\hline R1 & 0.32 & 2.20 & 2.43 & 5.97 & 0.79 & 0.47 & 0.36 & -0.65 & -0.70 & -0.45 \\
\hline $\mathrm{R} 2$ & 0.62 & 2.5 & 2.75 & 5.81 & 1.03 & 0.67 & 0.56 & -1.10 & -1.17 & -0.47 \\
\hline R3 & 0.04 & 2.17 & 2.42 & 5.65 & 0.07 & 0.23 & 0.00 & -0.81 & -1.10 & -0.85 \\
\hline R4 & 0.54 & nd & nd & nd & 1 & 0.63 & 0.37 & -0.87 & -0.65 & -0.41 \\
\hline R5 & 0.3 & 1.86 & 2.12 & 5.25 & 0.5 & 0.41 & 0.15 & -0.92 & -0.85 & -0.64 \\
\hline R6 & 0.3 & 1.58 & 1.83 & 5.27 & 0.82 & 0.42 & 0.3 & -0.82 & -0.39 & -0.37 \\
\hline R7 & -0.45 & 1.08 & 1.33 & 2.57 & -1.70 & -0.10 & -0.99 & -1.29 & -2.26 & -2.12 \\
\hline R8 & 0.3 & 2.05 & 2.31 & 5.1 & 0.49 & 0.46 & 0.24 & -0.97 & -1.14 & -0.71 \\
\hline R9 & 0.2 & 1.10 & 1.38 & 3.76 & 0.45 & 0.27 & 0.13 & -1.01 & -1.08 & -0.55 \\
\hline R10 & -0.55 & 0.78 & 1.04 & 2.18 & -1.95 & -0.19 & -1.18 & -1.36 & -2.20 & -2.27 \\
\hline R11 & -0.02 & 1.28 & 1.53 & 3.93 & -0.07 & 0.21 & -0.18 & -0.71 & -1.34 & -0.92 \\
\hline R12 & 0.36 & 1.84 & 2.13 & 4.7 & 0.35 & 0.44 & 0.08 & -1.23 & -1.36 & -0.81 \\
\hline R13 & -1.02 & 0.41 & 0.66 & 1.49 & -3.07 & -0.61 & -1.94 & -1.77 & -3.08 & -2.92 \\
\hline R14 & -1.56 & 1.14 & 1.39 & 3.00 & -4.09 & -1.15 & -2.35 & -2.22 & -3.03 & -3.40 \\
\hline
\end{tabular}

Regional N-S-oriented faulting systems, intercepted by NE-, NW- and WE-oriented transverse structures, likely act as preferentially uprising pathways for the deep-originated fluids. This hypothesis was supported by the Rc/Ra values (up to 1,26 in the thermal springs of Rosario de Coyaguayma), revealing the occurrence of significant amounts of mantle-derived $\mathrm{He}$ (up to 16\%) whose uprising to the surface through a thick crust implies the occurrence of deep tectonic structures. According to these indications, fluids emerging in the Olaroz thermal system may be regarded as the most distal manifestations of the Pairique hydrothermal reservoir.

The similarity between the ${ }^{87} \mathrm{Sr} /{ }^{86} \mathrm{Sr}$ ratios of the Rosario River (0.715; Garcia et al., 2020) and the ratios of rocks from the Pairique volcanic complex ( $\sim 0.716$; Kay et al., 2010$)$ represent an additional evidence of the strong relation between the hydrothermal fluid 
circulation to the north and the main source of recharge of the Salar de Olaroz. Hence, the chemistry of the thermal springs emerging in the Olaroz area, as well as that of the creeks (I4 and I5) and ephemeral lakes in the Rosario River alluvial fan, is dependent on the hydrothermal fluids brought to the salar from the north by Rosario River. Furthermore, it is affected by the dissolution/deposition processes mostly occurring at shallow depth within the salar where the arid climate caused strong evaporation, eventually producing extreme $\mathrm{Na}^{+}$and $\mathrm{Cl}^{-}$enrichments (Fig. 4a). The stoichiometric $\left(\mathrm{Mg}^{2+}+\mathrm{Ca}^{2+}\right) /\left(\mathrm{SO}_{4}^{2-}+\mathrm{HCO}_{3}^{-}\right)$ratios shown by most brines (Fig. 4b) are consistent with dissolution/deposition processes of calcite, dolomite, and gypsum. The heterogeneous spatial distribution of the minerals deposited by evaporation may explain the non-stoichiometric $\left(\mathrm{Ca}^{2+}+\mathrm{Mg}^{2+}\right)$ $/\left(\mathrm{SO}_{4}{ }^{2-}+\mathrm{HCO}_{3}{ }^{-}\right)$ratios characterizing the ephemeral lakes and the $\mathrm{R} 7$, R17, and R21 brines (Fig. 4b). The brines emerging at the peripheral zones (R7, R10, R11, R13, and R14) are over-saturated in carbonates, undersaturated in $\mathrm{SO}_{4}$-bearing salts (gypsum, anhydrite, glauberite, mirabilite and thenardite), and $\mathrm{Cl}$-bearing (halite and sylvite) minerals (Table 2). In contrast, brines located within the saline nucleus (R1, R2, R3, R4, R5, R6, R8, R9, and R12) are over-saturated in all these mineral species (Table 2). The highest TDS values are indeed found in brines located near the north-central part of the salar nucleus. In particular, the highly variable lithium concentrations in the brine $(115-1570 \mathrm{mg} / \mathrm{L}$ ) show their maximum in the north-central zones of the salar (R6), and decrease towards the salar margins (cf. López Steinmetz et al., 2018). Such a spatial distribution of the brine compositional features is roughly consistent with the concentric distribution of evaporites typically produced by the progressive deposition of salts having different solubility (Lopez et al., 1999; Warren, 2010). The effects of evaporation and salt dissolution on $\delta^{18} \mathrm{O}-\mathrm{H}_{2} \mathrm{O}$ values and TDS are clearly shown in Fig. 5: the former process is dominant for most ephemeral lakes, except for E4 (which during our surveys was not present at the surface). Although the composition of brines is controlled by the two processes (i.e., evaporation and salt dissolution), evaporation largely dominates over dissolution especially in samples collected at relatively shallow depths (R1, R3, R4, R5, and R6).

According to the criteria proposed by Hardie and Eugster (1970) and modified by Risacher et al. (1999), as well as Risacher and Fritz (2009), the chemical evolutionary pathways followed by waters affected by evaporation are based on the proportions between alkalinity (alk), calcium, magnesium, and sulfate. Four different evolutionary pathways were here considered, as follows:
Carbonated (or alkaline) path: alk $>\mathrm{Ca}^{2+}$ and alk $>\mathrm{Ca}^{2+}+\mathrm{Mg}^{2+}$

Direct sulfated and alkaline (or indirect) sulfated paths: alk $>\mathrm{Ca}^{2+}$ and alk $<$ $\mathrm{Ca}^{2+}+\mathrm{Mg}^{2+}$

Neutral sulfated path: alk $<\mathrm{Ca}^{2+}$ and alk $+\mathrm{SO}_{4}^{2-}>\mathrm{Ca}^{2+}$

Calcic path: alk $<\mathrm{Ca}^{2+}$ and alk $+\mathrm{SO}_{4}^{2-}<\mathrm{Ca}^{2+}$.

The Carbonated (or alkaline) pathway followed by the Ciénaga Bravaro River (I3) at initial stages of water evolution is typical of shallow groundwater. This water type evolves through Mg-salts precipitation towards the sulfated pathway influencing the ephemeral lakes related to this creek (E2 and E3). The composition of most inflow waters (I1, I2, I4 and I5) and E4 seems to be related to the sulfated pathway, leading to gypsum precipitation, whereas the chemical features of brines indicate a further evolution path towards the deposition of mirabilitehalite (Fig. 6). The peculiar chemical composition $\left(\mathrm{Na}^{+}-\mathrm{SO}_{4}^{2-}\right.$ type) of the Archibarca River (I2; Table 1) is likely related to the weathering of volcanic rocks of the Cerro Bayo de Archibarca, which are affected by a widespread advanced argillic (alunite-rich) hydrothermal alteration (Seggiaro et al., 2015). The Ciénaga Bravaro stream (I3), before reaching the evaporite zone (Fig. 1), is in contact with pre-lower Miocene sedimentary sequences at a relatively limited extent, as shown by its low TDS values $(<1800 \mathrm{mg} / \mathrm{L})$ and its $\mathrm{Na}^{+}-\mathrm{HCO}_{3}^{-}$composition.

As far as the Li origin and fate are concerned, it is worth noting that the Rosario River has a relatively high concentration of $\mathrm{Li}(16 \mathrm{mg} / \mathrm{L})$, i.e. more than fivefold higher than that measured in the Archibarca River (3 $\mathrm{mg} / \mathrm{L}$ ). A strong $\mathrm{Li}^{+}$enrichment was also measured (up to $29 \mathrm{mg} / \mathrm{L}$ ) in thermal springs that have a hydrological connection with the Rosario River (Rosario de Coyaguayma, Pairique, and Cono Panizo), which were ascribed to enhanced rock leaching (Peralta Arnold et al., 2017), including peraluminous volcanic rock and ignimbrites both characterized by high Li concentrations (Borda et al., 2019; Sarchi et al., 2019). Meixner et al. (2019), based on Li isotopic data, suggested that the deep Proterozoic-Paleozoic crystalline basement and its sedimentary derivatives also represented a significant Li source. Hence, the extremely high concentrations characterizing the Olaroz brines are due to (i) Li-rich hydrothermal type waters brought to the salar by the Rosario River, (ii) evaporation mostly affecting the former waters within the basin, and (iii) deposition/dissolution processes regulating the concentrations of ions, which in turn form salts when saturation conditions are reached (e.g., calcite, gypsum, and halite; Fig. 7).
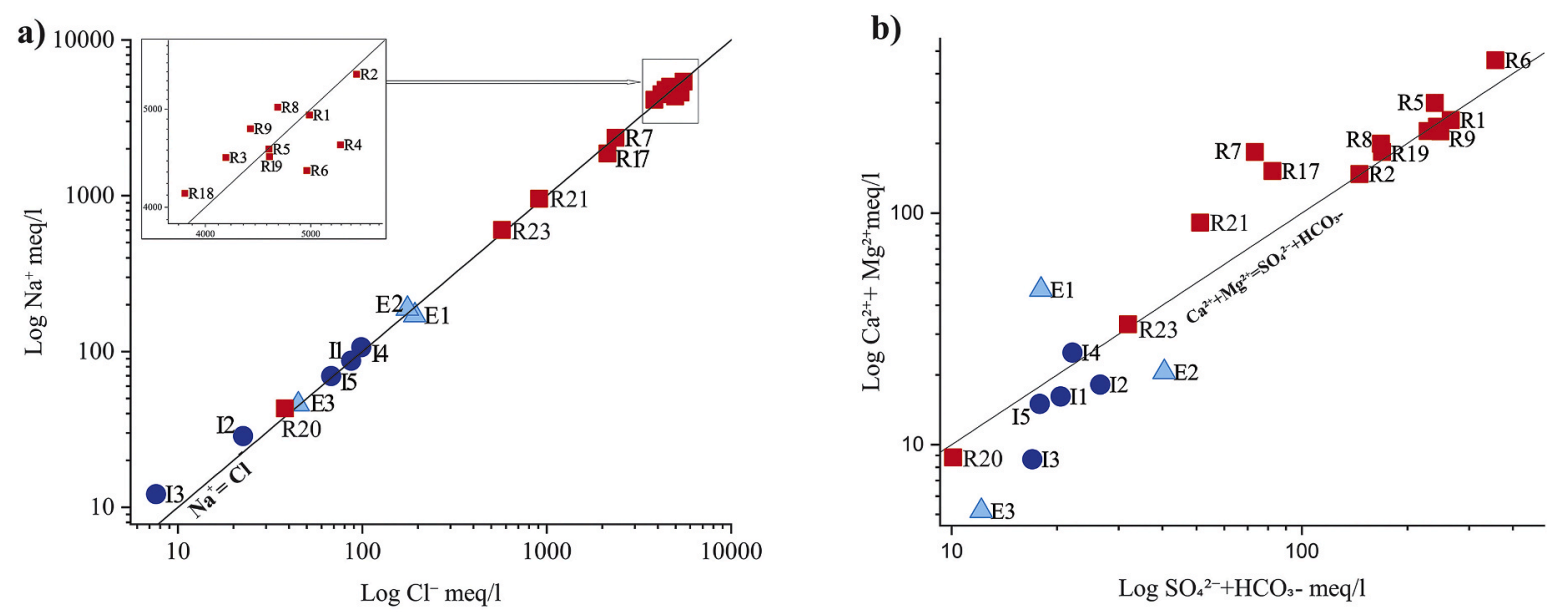

Inflows

$\triangle$ Ephemeral lakes

Brines

Fig. 4. $\mathrm{Na}^{+}$vs. $\mathrm{Cl}^{-}$(a), and $\left(\mathrm{Ca}^{2+}+\mathrm{Mg}^{2+}\right)$ vs. $\left(\mathrm{SO}_{4}^{2-}+\mathrm{HCO}_{3}^{2-}\right)$ (b) binary diagrams for waters from the Salar de Olaroz. Concentrations are in meq/L. Symbols are comparable to Fig. 1. 


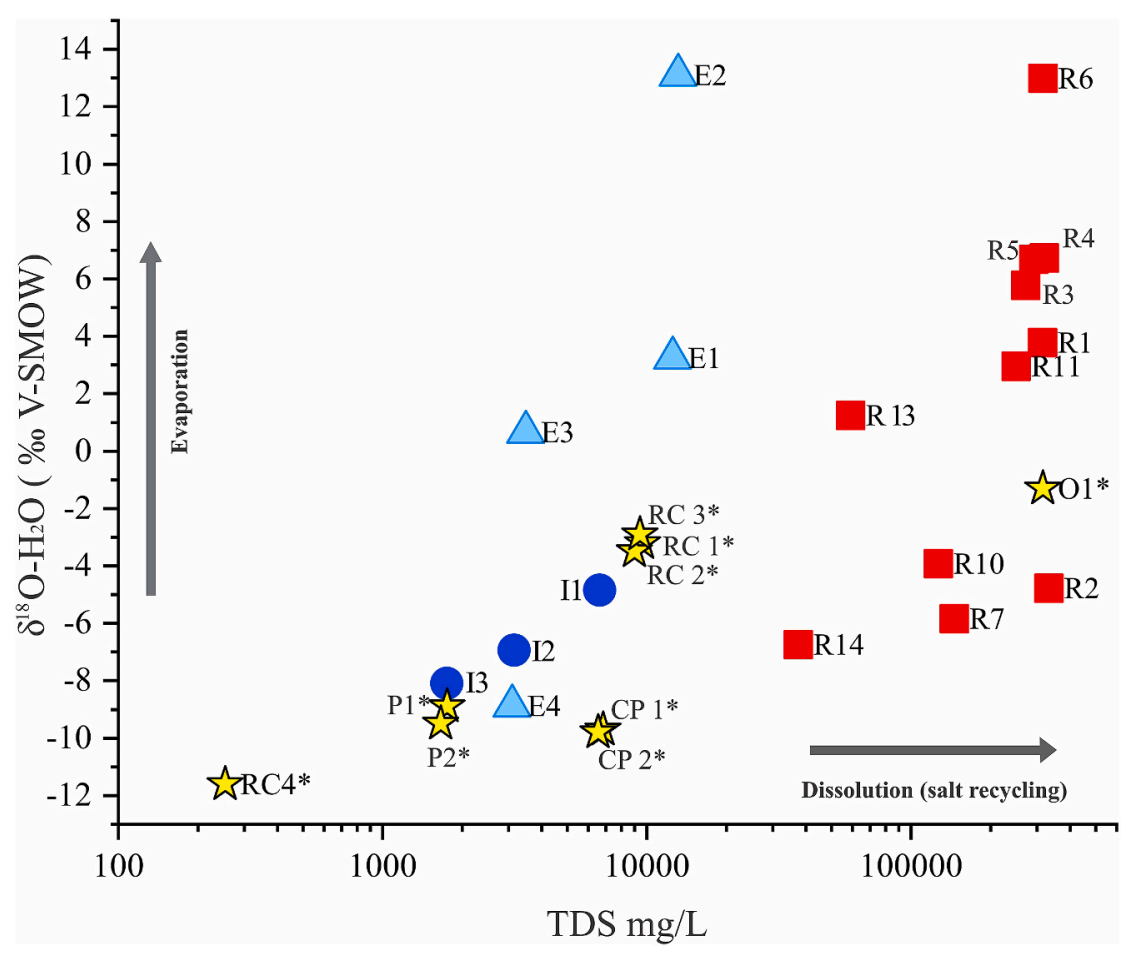

Fig. 5. $\delta^{18} \mathrm{O}-\mathrm{H}_{2} \mathrm{O}(\% \mathrm{~V}$-SMOW) vs. TDS (mg/L) binary diagram of waters from the Salar de Olaroz. Symbols are comparable to Fig. 1; star: thermal waters from Peralta Arnold et al. (2017).

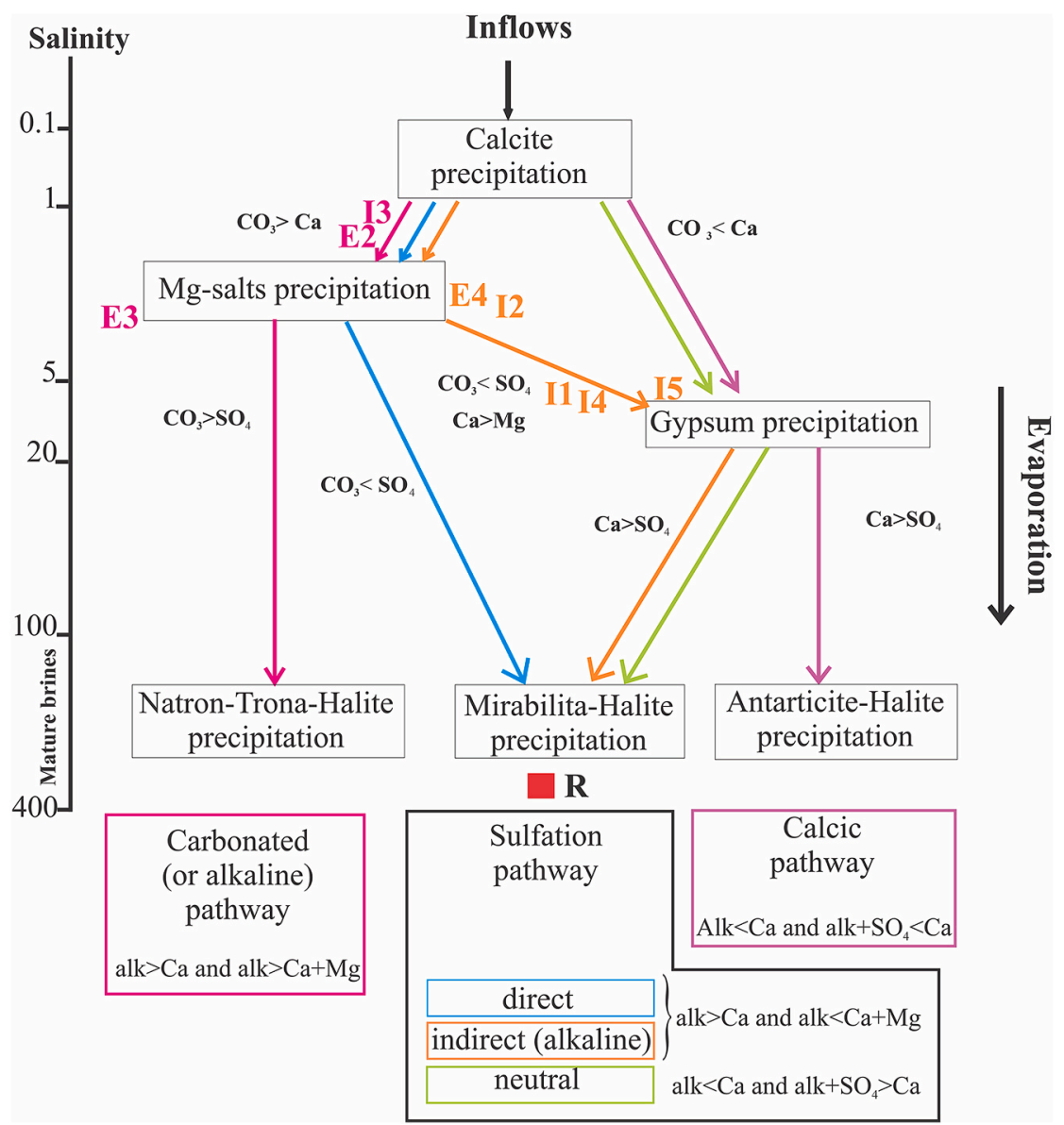

Fig. 6. Flow sheet diagram showing possible evolution pathways of inflow waters from Salar de Olaroz (modified from Hardie and Eugster, 1970; Risacher and Fritz, 2009). The pathways (trends of colored arrows) depend on TDS (in $\mathrm{g} / \mathrm{L}$ ) and relative concentrations (in $\mathrm{mg} / \mathrm{L}$ ) of the main solutes. 


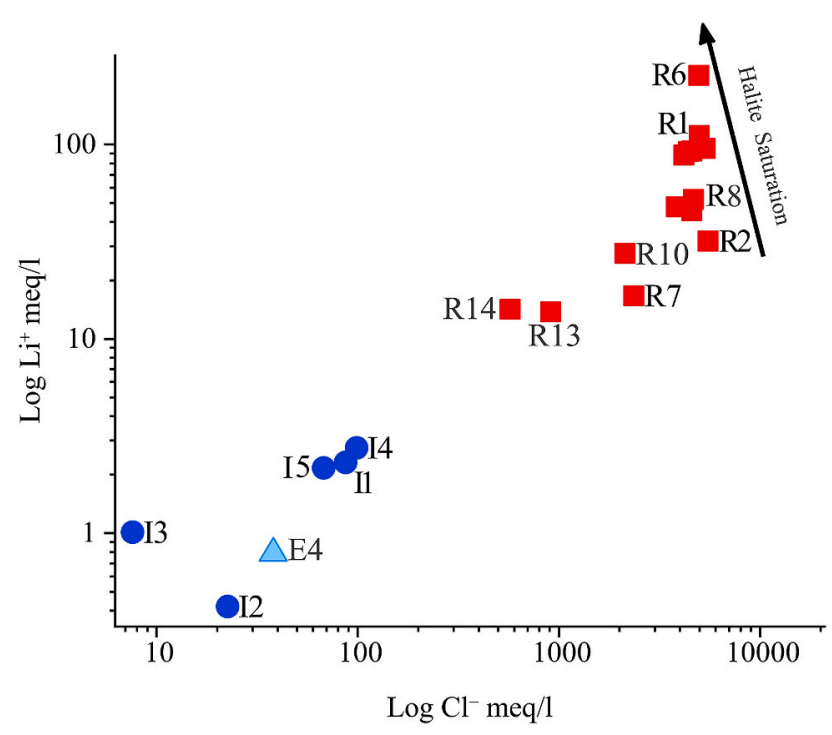

Fig. 7. $\mathrm{Li}^{+}$vs. $\mathrm{Cl}^{-}$binary diagram of waters from the Salar de Olaroz. Symbols are comparable to Fig. 1.

In summary, the Li-rich brines of the Salar de Olaroz are ruled by (i) climate, (ii) contribution of hydrothermal fluids, and (iii) secondary dissolution/evaporation processes. As a result, the concentration of $\mathrm{Li}$ in the brines are several orders of magnitude higher than that measured in hydrothermal sources and in the Rosario and Archibarca Rivers, since the highly soluble minerals able to incorporate this element can form only when water evaporation is almost complete. Currently, the Salar de Olaroz contains the second most important lithium mine in Argentina, after that of Salar del Hombre Muerto (ca. $25^{\circ} 24^{\prime} \mathrm{S}-67^{\circ} 07^{\prime} \mathrm{W}$ ). Lithium is exploited as $\mathrm{Li}_{2} \mathrm{CO}_{3}$ that deposits in the processing plants where the pumped brine is exposed to extreme evaporation (Garcia et al., 2020). The production of Li-salts involves two sources of water (Orocobre, 2018): brines and brackish water, the latter being possibly provided by the Archibarca River. It is worth noting that the water usage for lithium carbonate production may significantly modify the water balance of the basin, leading to dramatic consequences for this delicate natural system. Moreover, although Li exploitation is to be considered an important opportunity for the economic development of the region, the socio-environmental impact of mining activity on local communities needs to be urgently evaluated (Agusdinata et al., 2018).

\section{Conclusions}

The Rosario River is the main source of recharge to the Salar de Olaroz and its composition depends on the leachate from the basin rocks, and the hydrothermal systems, mainly located north of the salar, that interact with Li-rich volcanic rocks, Ordovician sedimentary rocks, and, possibly, a deep Neoproterozoic to Lower Paleozoic crystalline basement. In contrast, the Archibarca and Ciénaga Bravaro Rivers are characterized by $\mathrm{Na}^{+}-\mathrm{SO}_{4}^{2-}$ and $\mathrm{Na}^{+}-\mathrm{HCO}_{3}^{-}$compositions, respectively: the Archibarca composition is likely related to interaction with $\mathrm{SO}_{4}^{2-}$-rich rocks from the Cerro Bayo de Archibarca, which is in turn is largely affected by alunite-rich epithermal alteration, whereas the Cienaga Bravaro waters are likely in contact with carbonate-rich lithologies of Salta Group. The chemistry of the Olaroz brines is mainly ruled by the geochemical features of the Rosario River, whose evolution, as a consequence of the strong evaporation, follows the sulfation pathway. According to this hypothesis, the concentrations of the main ions in the brine, such as $\mathrm{HCO}_{3}^{-}, \mathrm{SO}_{4}^{2-}$ and $\mathrm{Cl}$, are controlled by calcite, gypsum and halite deposition/dissolution that may alternatively occur depending on the amount of supplied water versus evaporation. On the contrary, $\mathrm{Li}$ can reach extremely high concentrations as this metal is not limited by the mineral deposition that affects other ions.

Hence, the combination of favorable geological and hydrological settings with chemical-physical processes induced by a peculiar hyperarid climate are the key factors the explain the origin of the huge Li reservoir of Salar de Olaroz.

\section{Author statement}

All persons who meet authorship criteria are listed as authors, and all authors certify that they have participated sufficiently in the work to take public responsibility for the content, including participation in the concept, design, analysis, writing, or revision of the manuscript.

\section{Declaration of competing interest}

None.

\section{Acknowledgments}

Authors thanks the financial support of the CONICET (PIO-2015/ 201614020140100010CO), ANPCyT (FonCyT, FITR Fonarsec 2013 and PICT-V-2014-3654) and PUE INECOA CONICET 2017, whose support facilities and funds used in this investigation. M.G. Franco, Y. Peralta Arnold, C. Santamans and C. Jofré acknowledge doctoral fellowships from CONICET. We thank to Dr. Ernesto Calvo for providing analytical support. The anonymous reviewers and the invited editor are warmly acknowledged for their useful suggestions that helped the authors to improve the original version of the manuscript.

\section{References}

Agusdinata, D.R., Liu, W., Eakin, H., Romero, H., 2018. Socio-environmental impacts of lithium mineral extraction: towards a research agenda. Environ. Res. Lett. 13, 123001.

Albanesi, G.L., Ortega, G., 2016. Conodont and graptolite biostratigraphy of the ordovician system of Argentina. Stratigraphy \& timescales 1, 61-121.

Alonso, R.N., 1986. Ocurrencia, Posición Estratigráfica y Génesis de los Depósitos de Boratos de la Puna Argentina. PhD Thesis. Univ Nac de Salta, p. 196.

Bahlburg, H., Breitkreuz, C., Maletz, J., Moya, M.C., Salfity, J.A., 1990. The Ordovician sedimentary rocks in the northern Puna of Argentina and Chile: new stratigraphical data based on graptolites. Newsl. Stratigr. 23 (2), 69-89.

Borda, L.G., Franco, M.G., Córdoba, F.E., García, M.G., 2019. Distribución de Li en facies clásticas y químicas del Salar de Olaroz, puna norte, Jujuy. In: Proceedings of the 5th Reunión Argentina de Geoquímica de la Superficie (V RAGSU), ISBN 978-98796296-7-3, pp. 146-149.

Buitrago, L.G., Larran, M.T., 2000. El clima de la Provincia de Jujuy. Cátedra de Climatología y Fenología Agrícolas. Universidad Nacional de Jujuy, Facultad de Ciencias Agrarias, p. 39.

Caffe, P.J., Trumbull, R.B., Coira B.L., Coira, Romer, R.L., 2002. Petrogenesis of early Neogenemagmatism in the northern Puna; implications for magma genesis and crustal processes in the Central Andean plateau. J. Petrol. 43 (5), 907-942. https:// doi.org/10.1093/petrology/43.5.907.

Chiodi, A., Tassi, F., Báez, W., Filipovich, R., Bustos, E., Galli, M.G., Suzaño, N., Ahumada, M.F., Viramonte, Giordano, G., Pecorino, G., Vaselli, O., 2019. Preliminary conceptual model of the Cerro Blanco caldera-hosted geothermal system (Southern Puna, Argentina): inferences from geochemical investigations. J. S. Am. Earth Sci. 94, 102213.

Coira, B., Kay, S., Viramonte, J.G., 1993. Upper Cenozoic magmatic evolution of the Argentine Puna. A model for changing subduction geometry. Int. Geol. Rev. 35, 677-720.

Coira, B., Caffe, P.J., Ramirez, A., Chayle, W., Diaz, A., Rosas, S., Perez, B., Orozco, O., Marinez, M., 2004. Hoja Geológica 2366-I/2166-III: Mina Pirquitas, Provincia de Jujuy, 1:250,000. Servicio Geológico Minero Argentino, Buenos Aires.

Eugster, H.P., 1980. Geochemistry of evaporitic lacustrine deposits. Annu. Rev. Earth Planet Sci. 8 (1), 35-63.

Eugster, H.P., Hardie, L.A., 1978. Saline lakes. In: Lerman, A. (Ed.), Chemistry, Geology and Physics of Lakes. Springer, pp. 273-293.

Flexer, V., Baspineiro, C.F., Galli, C.I., 2018. Lithium recovery from brines: a vital raw material for green energies with a potential environmental impact in its mining and processing. Sci. Total Environ. 639, 1188-1204. https://doi.org/10.1016/j. scitotenv.2018.05.223.

Franco, M.G., Borda, L., García, M.G., López Steinmetz, R.L., Flores, P., Córdoba, F., 2016. Geochemical and sedimentological characterization of the salar de Olaroz, northern argentinean puna, central Andes. In: 3rd International Workshop on Lithium, Industrial.

Franco, M.G., Santamans, C., Flores, P., Piovano, L., Córdoba, F., 2018. Caracterización de los subambientes del Salar de Olaroz, Puna Norte. In: Proceedings of the 7th 
Congreso Argentino de Geomorfología y Cuaternario. VII GEOCUAR) ISSN, pp. 2591-6653.

García, M.G., Borda, L.G., Godfrey, L.V., López Steinmetz, R.L., Losada-Calderón, A., 2020. Characterization of lithium cycling in the Salar De Olaroz, Central Andes, using a geochemical and isotopic approach. Chem. Geol. 531, 119340 https://doi. org/10.1016/j.chemgeo.2019.119340.

Garreaud, R., Vuille, M., Clement, A.C., 2003. The climate of the Altiplano: observed current conditions and mechanisms of past changes. Palaeogeogr. Palaeoclimatol. Palaeoecol. 194 (1-3), 5-22.

Garreaud, R.D., Vuille, M., Compagnucci, R., Marengo, J., 2009. Present-day south american climate. Palaeogeogr. Palaeoclimatol. Palaeoecol. 281 (3-4), 180-195. https://doi.org/10.1016/j.palaeo.2007.10.032.

Godfrey, L.V., Chan, L.-H., Alonso, R.N., Lowenstein, T.K., McDonough, W.F., Houston, J., Li, J., Bobst, A., Jordan, T.E., 2013. The role of climate in the accumulation of lithium-rich brine in the Central Andes. Appl. Geochem. 38, 92-102.

Hardie, L., Eugster, H., 1970. The Evolution of Closed-Basin Brines, vol. 3. Mineral Society of America Special Publication Paper, pp. 273-290.

Hardie, L.A., Smoot, J.P., Eugster, H.P., 1978. Saline lakes and their deposits: a sedimentological approach. In: Modern and Ancient Lake Sediments. Spec. Publs. Int Ass. Sediment, vol. 2, pp. 7-41.

Houston, J., Butcher, A., Ehren, P., Evans, K., Godfrey, L., 2011. The evaluation of brine prospects and the requirement for modifications to filing standards. Econ. Geol. 106 (7), 1225-1239.

Kay, S.M., Coira, B., Caffe, P.J., Chen, C.-H., 2010. Regional chemical diversity, crustal and mantle sources and evolution of central Andean Puna plateau ignimbrites. J. Volcanol. Geoth. Res. 198 (1-2), 81-111.

Kesler, S.E., Gruber, P.W., Medina, P.A., Keoleian, G.A., Everson, M.P., Wallington, T.J., 2012. Global lithium resources: relative importance of pegmatites, brine and other deposits. Ore Geol. Rev. 48, 55-69. https://doi.org/10.1016/j. oregeorev.2012.05.006.

Langelier, W.F., Ludwig, H.F., 1942. Graphical methods for indicating the mineral character of natural waters. J. Am. Water Works Assoc. 34 (3), 335-352.

López, P.L., Auqué, L.F., Garcés, I., Chong, G., 1999. Características geoquímicas y pautas de evolución de las salmueras superficiales del Salar de Llamara, Chile. Rev. Geol. Chile 26 (1), 89-108.

López Steinmetz, R.L., 2017. Lithium- and boron-bearing brines in the Central Andes: exploring hydrofacies on the eastern Puna plateau between $23^{\circ}$ and $23^{\circ} 30^{\prime} \mathrm{S}$. Miner. Deposita 52 (1), 35-50.

López Steinmetz, R.L., Salvi, S., García, M.G., Peralta Arnold, Y., Beziat, D., Franco, G. Constantini, O., Córdoba, F., Caffe, P.J., 2018. Northern puna-scale survey of Librine deposits in the Andes of NW Argentina. J. Geochem. Explor. 190, 26-38. https://doi.org/10.1016/j.gexplo.2018.02.013.

Lowenstein, T., Risacher, F., 2009. Closed basin brine evolution and the influence of $\mathrm{Ca}-\mathrm{Cl}$ inflow waters. Death valley and bristol dry lake, California, QaidamBasin, China, and salar de Atacama, Chile. Aquat. Geochem. 15, 71-94.

Maro, G., Caffe, P.J., 2017. Neogene monogenetic volcanism from the Northern Puna region: products and eruptive styles. In: Németh, K., Carrasco-Núnez, G., ArandaGómez, J.J., Smith, I.E.M. (Eds.), Monogenetic Volcanism, vol. 446. Geological Society of London, Special Publications, pp. 337-359.

Marquillas, R.A., Del Papa, C., Sabino, I.F., 2005. Sedimentary aspects and paleoenvironmental evolution of a rift basin: Salta Group (Cretaceous-Paleogene), northwestern Argentina. International Journal of Earth 94 (1), 94-113.

Meixner, A., Sarchi, C., Lucassen, F., Becchio, R., Caffe, P.J., Lindsay, J., Rosner, M., Kasemann, S.A., 2019. Lithium concentrations and isotope signatures of Palaeozoic basement rocks and Cenozoic volcanic rocks from the Central Andean arc and backarc. Miner. Deposita. https://doi.org/10.1007/s00126-019-00915-2.

Moraga, A., Chong, G., Fortt, M.A., Henríquez, H., 1974. Estudio geológico del Salar deAtacama. In: Provincia de Antofagasta, vol. 29. Boletín del Instituto de Investigaciones Geológicas., p. 56

Morales, M.S., Carilla, J., Grau, H.R., Villalba, R., 2015. Multi-century lake area changes in the Southern Altiplano: a tree-ring-based reconstruction. Clim. Past 11 (9), 1139-1152.

Moran, B.J., Boutt, D.F., Munk, L.A., 2019. Stable and radioisotope systematics reveal fossil water as fundamental characteristic of arid orogenic-scale groundwater systems. Water Resources Research. https://doi.org/10.1029/2019WR026386.

Munk, L.A., Hagedorn, B., Sjostrom, D., 2011. Seasonal fluctuations and mobility of arsenic in groundwater resources, Anchorage, Alaska. Appl. Geochem. 26 (11), 1811-1817.

Munk, L.A., Hynek, S.A., Bradley, D., Boutt, D., Labay, K., Jochens, H., 2016. Lithium brines: a global perspective. Rev. Econ. Geol. 18, 339-365.

Munk, L.A., Boutt, D.F., Hyneck, S., Moran, B., 2018. Hydrogeochemical fluxes and processes contributing to the formation of lithium-enriched brines in a hyper-arid continental basin. Chem. Geol. 493, 37-57. https://doi.org/10.1016/j. chemgeo.2018.05.013.

Orberger, B., Rojas, W., Millot, R., Flehoc, C., 2015. Stable isotopes (Li, O, H) combined with chemistry: powerful tracers for Li origins in Salar deposits from the Puna region, Argentina. Procedia Earth Planet. Sci. 13, 307-311.

Orocobre, 2019. Olaroz Lithium Project. https://www.orocobre.com/operations/salar -de-olaroz/-. (Accessed 20 May 2019).

Orocobre, 2018. Sustainability report Salar de Olaroz Lithium Facility. https://www.or ocobre.com/corporate-responsibility/sustainability-report/-. (Accessed 3 May 2020).

Peralta Arnold, Y.J., Cabssi, J., Tassi, F., Caffe, J.P., Vaselli, O., 2017. Fluid geochemistry of a deep-seated geothermal resource in the Puna plateau (Jujuy Province, Argentina). J. Volcanol. Geoth. Res. 338, 121-134. https://doi.org/10.1016/j. jvolgeores. 2017.03.030.

Perkins, J.P., Finnegan, N.J., Henderson, S.T., Rittenour, T.M., 2016. Topographic constraints on magma accumulation below the actively uplifting Uturuncu and Lazufre volcanic centers in the Central Andes. Geosphere 12 (4), 1078-1096.

Rettig, S.L., Jones, B.F., Risacher, F., 1980. Geochemical evolution of brines in the Salar de Uyuni, Bolivia. Chem. Geol. 30 (1-2), 57-79.

Risacher, F., Fritz, B., 1991. Quaternary geochemical evolution of the salar of uyuni and coipasa, central Altiplano, Bolivia. Chem. Geol. 90 (3-4), 211-231.

Risacher, F., Fritz, B., 2000. Bromine geochemistry of salar de Uyuni and deeper salt crusts, Central Altiplano, Bolivia. Chem. Geol. 167 (3-4), 373-392.

Risacher, F., Fritz, B., 2009. Origin of salt and brine evolution of Bolivian and Chilean Salars. Aquat. Geochem. 15 (1-2), 123-157.

Risacher, F., Alonso, H., Salazar, C., 1999. Geoquímica de aguas en cuencas cerradas: I, II y III Regiones - Chile. In: Convenio de Cooperación ORSTOM - DGA - UCN - IRD, SIT 51, Santiago de Chile, p. 781.

Risacher, F., Alonso, H., Salazar, C., 2003. The origin of brines and salts in Chilean Salars: a hydrochemical review. Earth Sci. Rev. 63 (3-4), 249-293.

Sarchi, C., Meixner, A., Lucassen, F., Caffe, P.J., Beccio, R., Kasemann, S.A., 2019 Signaturas isotópicas de Li y Sr del basamento paleozoico y vulcanitas cenozoicas, puna norte. implicancias en la generación de salmueras ricas en Li. In: Proceedings of the XIII Congreso de Mineralogía, Petrología Ignea y Metamórfica, y Metalogénesis (XIII MINMET y IV PIMMA), ISBN 978-987-86-1704-6, pp. 377-378.

Schwab, K., 1973. Die Stratigraphie in der umgebung des salar Cauchari, vol. 43. Geotekt. Forsch, Germany, p. 168.

Seggiaro, R.E., 1994. Petrología, geoquímica y mecanismos de erupción del complejovolcánico Coranzulí. Univ Nac de Salta, p. 181. Ph.D. thesis.

Seggiaro, R.E., Becchio, R., Bercheñi, V., Ramallo, L., Franchi, M., 2015. Hoja Geológica 2366-III: Susques, 1:250,000. Servicio Geológico Minero Argentino, Buenos Aires.

Smoot, J.P., Lowenstein, T.K., 1991. Depositional environments of non-marine evaporites. In: Melvin, En J. (Ed.), Evaporites, Petroleum and Mineral Resources. Developments in Sedimentology, vol. 50. Elsevier, pp. 189-347.

Soler, M.M., Caffe, P.J., Coira, B.L., Onoe, A.T., Kay, S.M., 2007. Geology of the Vilama caldera: a new interpretation of a large-scale explosive event in the Central Andean plateau during the Upper Miocene. J. Volcanol. Geoth. Res. 164 (1-2), 27-53.

Tapia, J., Murray, J., Ormachea, M., Tirado, N., Nordstrom, D.K., 2019. Origin, distribution, and geochemistry of arsenic in the Altiplano -Puna plateau of Argentina, Bolivia, Chile, and Perú. Sci. Total Environ. 678, 309-325.

Turner, J.C., 1959. Estratigrafía del Cordón de Escaya y la Sierra de Rinconada, Jujuy. Rev. Asoc. Geol. Argent. 15 (1), 15-39.

Turner, J.C., 1964. Descripción geológica de la Hoja 2b La quiaca (provincia de Jujuy), 103. Boletín del Instituto Nacional de Geología y Minería, p. 109.

Vuille, M., 1999. Atmospheric circulation over the Bolivian Altiplano during dry and wet periods and extreme phases of the Southern Oscillation. Int. J. Climatol.: J. R. Meteorol. Soc. 19 (14), 1579-1600.

Vuille, M., Keimig, F., 2004. Interannual variability of summertime convective cloudiness and precipitation in the central Andes derived from ISCCP-B3 data. J. Clim. 17 (17), 3334-3348.

Vuille, M., Burns, S.J., Taylor, B.L., Cruz, F.W., Bird, B.W., Abbott, M.B., Kanner, L.C., Cheng, H., Novello, V.F., 2012. A review of the South American monsoon history as recorded in stable isotopic proxies over the past two millennia. Clim. Past 8 (4), 1309-1321.

Warren, J.K., 2010. Evaporites through time: tectonic, climatic and eustatic controls in marine and nonmarine deposits. Earth Sci. Rev. 98 (3), 217-268. https://doi.org/ 10.1016/j.earscirev.2009.11.004.

Weissmann, G.S., Hartley, A.J., Scuderi, L.A., Nichols, G.J., Owen, A., Wright, S., Felicia, A.L., Holland, F., Anaya, F.M.L., 2015. Fluvial geomorphic elements in modern sedimentary basins and their potential preservation in the rock record: a review. Geomorphology 250, 187-219. https://doi.org/10.1016/j. geomorph.2015.09.005. 